\title{
PENDIDIKAN KESEHATAN PENCEGAHAN SKABIES DI PONDOK PESANTREN AL-ARIFIN
}

\author{
Henri Setiawan, Heri Ariyanto, Fidya Anisa Firdaus, Reffi Nantia Khaerunnisa
}

\author{
Program Studi Keperawatan, STIKes Muhammadiyah Ciamis \\ henrisetiawan1989@gmail.com
}

\begin{abstract}
Scabies is a skin disease caused by investment and sensitivity by Sarcoptes scabei, often found in Islamic boarding schools because the place was humid, and the students' knowledge about lifestyle was lack. Health Education was intended to increase the students' experience at Al-Arifin Islamic boarding school about scabies and prevent it. The implementation method in these community service activities was started from planning, assessment, implementation, and evaluation. Health education was carried out through lectures and discussion by leaflets and PowerPoint presentations. The results showed $70.00 \%$ of participants gave an excellent rating of health education. Scabies health education activities provide benefits to improving public health, specifically in the boarding school environment. Health education about scabies in the boarding school environment was very useful for improving students' knowledge.
\end{abstract}

Keywords: boarding school, health education, scabies

\begin{abstract}
Abstrak
Skabies merupakan penyakit kulit yang disebabkan oleh investasi dan sensititasi oleh tungau Sarcoptes scabei. Penyakit ini sering di temukan di pondok pesantren, karena tempatnya yang lembab serta rendahnya wawasan santri tentang perilaku hidup bersih dan sehat. Kegiatan pendidikan kesehatan ini bertujuan untuk meningkatkan pengetahuan para santri di pondok pesantren Al-Arifin tentang pencegahan skabies yang sering terjadi di pesantren. Metode yang digunakan dalam kegiatan pengabdian ini terdiri dari tahap perencanaan, assessment permasalahan santri, pelaksanaan kegiatan, dan diakhiri dengan kegiatan evaluasi sebagai tolak ukur tingkat keberhasilan kegiatan. Pendidikan kesehatan di lakukan dengan cara ceramah dan sesi tanya jawab, media pendidikan menggunakan leaflet dan PowerPoint Presentation. Hasil evaluasi menunjukan 70,00\% partisipan dalam kegiatan ini memberikan penilaian sangat baik. Kegiatan pendidikan kesehatan tentang pencegahan skabies memberikan manfaat dalam meningkatkan pengetahuan pada kelompok komunitas di lingkungan pesantren, sehingga derajat kesehatan masyarakat meningkat.
\end{abstract}

Kata kunci: pendidikan kesehatan, pondok pesantren, scabies

\section{PENDAHULUAN}

World Health Organization (WHO) menyebutkan skabies adalah penyakit infeksi kulit akibat investasi dan sensitivasi oleh tungau betina Sarcoptes scabiei varieta hominis yang termasuk dalam kelas Arachnida. Prevalensi skabies di seluruh dunia dilaporkan sekitar 300 juta kasus per tahun (Haque et al., 2019).

Menurut International Alliance for the Control of Scabies (IACS) kejadian skabies terjadi mulai dari 0,3\% menjadi 46\%. Berdasarkan data Depkes RI pada tahun 2015, prevalensi penyakit kulit di seluruh Indonesia adalah sebesar $8,46 \%$. Peningkatan angka prevalensi terjadi pada tahun 2016 sebesar 9\% yang menempatkan penyakit skabies pada urutan ketiga. Selain itu, ada 13 provinsi dengan prevalensi diatas rata-rata nasional salah satunya Jawa Barat. (Riskesdas, 2013).

Insiden skabies di Indonesia masih sangat tinggi terutama pada 
lingkungan komunal seperti lingkungan pesantren (Muller \& Brinker, 2020). Penelitian yang dilakukan oleh Ma'rufi et al (2005), Kuspiantoro (2005) dan Sungkar (2017) menyatakan bahwa prevalensi skabies di pondok pesantren yang padat penghuni dengan hygiene yang buruk mencapai $78,7 \%$. Sedangkan pondok pesantren yang memiliki tingkat hygiene yang baik, prevalensinya hanya kisaran 3,8\%. INi menunjukan adanya pengaruh antara hygiene dengan insiden skabies.

Skabies memang tidak membahayakan kehidupan manusia (Cheng et al., 2020), namun sangat mengganggu rasa nyaman dan dapat menurunkan aktivitas serta produktivitas akibat dari gejala utamanya berupa gatal yang sering muncul di malam hari (Sara, Haji, \& Gebretsadik, 2018). Penyakit kulit ini sering ditemukan di lingkungan yang penduduknya sangat padat, kumuh, dan lingkungan dengan tingkat kebersihan yang rendah (Wijayanti \& Ainiyah, 2019). Skabies dapat menyerang semua golongan usia dan jenis kelamin, diantaranya pada anak-anak usia sekolah, remaja maupun orang dewasa, baik pada laki-laki maupun perempuan (Srinivas et al., 2019). Penyakit skabies dapat ditularkan secara langsung setelah ada kontak dengan penderita skabies, seperti berjabat tangan dan beraktivitas bersama dengan sentuhan (Wochebo, Haji, \& Asnake, 2019). Penularan secara tidak langsung dapat terjadi ketika memakai pakaian, handuk, tempat tidur dan fasilitas umum yang di pakai secara bersama-sama (Bear et al., 2020).

Skabies dianggap tidak mengancam jiwa manusia, sehingga hal ini menjadi penyebab penyakit ini sering diabaikan dan luput dari perhatian masyarakat sehingga prioritas penanganannya rendah. Mendukung pernyataan tersebut, WHO pada tahun 2009 menyatakan bahwa skabies merupakan penyakit kulit yang terabaikan (Heukelbach \& Feldmeier, 2019). Padahal skabies dapat menimbulkan lesi pada kulit serta gatalgatal yang membuat tidak nyaman (Engelman et al., 2020). Penderita sering menggaruk area yang gatal-gatal sehingga mengakibatkan infeksi sekunder oleh bakteri Group A Streptococci (GAS) serta Staphylococcus aureus (Retha \& Sawitri, 2020). Komplikasi akibat investasi dari bakteri tersebut sering terjadi pada usia anak-anak terutama di negara berkembang (Anderson \& Strowd, 2017). Hal tersebut sesuai dengan penelitian yang dilakukan oleh Sudarsono (2011) di Jawa Barat yang menunjukkan prestasi belajar santri menjadi menurun dibandingkan sebelum menderita skabies.

Itulah beberapa penjelasan terkait penyebab penyakit skabies. Berbagai faktor dapat menjadi pendorong insidens scabies termasuk diantaranya faktor lingkungan. Namun upaya preventif dapat dilakukan dengan modifikasi lingkungan serta peningkatan wawasan tentang perilaku hidup bersih dan sehat. Masyarakat dan komunitas khususnya para santri di pondok pesantren dapat didorong untuk meningkatkan pengetahuan dengan menghindari faktor-faktor penyebab terjadinya skabies. Salah satu bentuk upaya yang dapat dilakukan adalah dengan melakukan pendidikan kesehatan sebagai bagian dari promosi kesehatan yang dilaksanakan oleh tenaga kesehatan. Perawat dalam hal ini memiliki peran utama untuk melakukan upaya preventif, rehabilitatif dan kuratif (Farihah \& Azizah, 2017).

Pondok pesantren (ponpes) AlArifin merupakan ponpes yang berada diwilayah Kabupaten Ciamis yang 
terdiri dari 80 orang santri menyatakan tidak mengetahui mengenai personal hygiene yang baik karena kurangnya pendidikan kesehatan terhadap penyakit skabies. Personal artinya perorangan atau individu. Sedangkan hygiene adalah ilmu yang berhubung dengan kesehatan serta pemeliharaannya. Jadi personal hygiene merupakan upaya perawatan individu terhadap kesehatannya seperti menjaga kebersihan diri yang meliputi seperti kebersihan kulit dan kuku, gigi dan mulut, hidung, mata, telinga dan area genital (Erbenezer, 2019). Kemampuan melakukan hygiene berbeda-beda dapat dipengaruhi oleh kesehatan, kebiasaan, budaya, perkembangan, dan lingkungan (Abedassar, Dehesh, \& Reza, 2020). Kebersihan tangan menjadi faktor terpenting dalam personal hygiene (Uchejeso \& Obiora, 2020).

Adapun upaya kesehatan yang dilakukan oleh masyarakat untuk menjaga dan mengawasi faktor lingkungan yang dapat mempengaruhi terhadap kesehatan disebut dengan kebersihan lingkungan. Lingkungan yang kurang bersih menjadi salah datu faktor presipitasi terhadap prevalensi skabies. Beberapa penelitian menunjukan adanya hubungan yang kuat antara kebersihan lingkungan dengan insiden skabies. Salah satu unsur dalam kebersihan lingkungan adalah Sanitasi yang kebersihan tempat tinggal atau asrama.

Beberapa kegiatan penting yang dapat dilakukan untuk menjaga sanitasi lingkungan yang baik adalah dengan cara membersihkan berbagai peralatan milik pribadi santri, serta digunakan secara bersama-sama dengan santri lain. Selain itu, santri dapat menyapu dan mengepel lantai, mencuci peralatan makan, membersihkan kamar, serta membuang sampah pada tempatnya secara rutin dan terjadual. Dengan demikian, upaya menjaga kebersihan Sanitasi lingkungan akan terwujud dii berbagai sudut lingkungan seperti halaman depan dan belakang, saluran pembuangan air serta jalan yang biasa dilewati oleh santri di sekitar asrama (Fuhrmeister et al., 2020).

Sumber air bersih yang tersedia dan biasa digunakan untuk memenuhi kebutuhan sehari-hari harus memenuhi standar antara lain tidak berwarna atau bening, tidak berbau serta tidak berasa atau netral. Hal ini disebabkan bahwa Sanitasi lingkungan yang buruk memiliki hubungan yang kuat dengan insiden atau prevalensi skabies, apalagi bila didukung dengan pemukiman yang padat (Rosa et al, 2020). Ruang yang padat akibat banyaknya bangunan dapat menyebabkan penurunan jumlah sirkulasi udara serta pencahayaan matahari ke dalam ruangan (Miftahurrizqiyah et al, 2018). Kondisi seperti itu akan berdampak buruk terhadap kesehatan masyarakat sehingga menjadi faktor resiko insiden skabies.

Hasil observasi yang dilakukan secara langsung di pondok pesantren Al-Arifin menunjukan kamar dengan luas 2x4 meter dihuni oleh 7 santri dengan lima lemari dua pintu. Tentu saja kamar sekecil ini terlalu padat dan dapat berdampak pada berkurangnya cahaya matahari yang masuk ke dalam kamar, sehingga ruangan menjadi lembab.

Beberapa santri kadang-kadang masih menggunakan handuk secara bersamaan, tidak mengganti pakaian setelah mandi, serta menggunakan peralatan mandi bersama.

Berdasarkan beberapa temuan tersebut, maka perlu ada upaya yang menjadi fokus utama berdasarkan kesepakatan bersama untuk meningkatan pengetahuan tentang skabies dan cara pencegahannya. Upaya 
yang dilakukan untuk mengatasi keadaan tersebut yaitu dengan mengadakan sebuah kegiatan berupa pendidikan kesehatan.

\section{METODE}

Kegiatan pengabdian dilaksanak an dalam bentuk pendidikan kesehatan pada tanggal 3 Desember 2019 bertempat di aula pondok pesantren AlArifin Jln. Karanggedang Kelurahan Linggasari, Kecamatan Ciamis, Kabupaten Ciamis yang diikuti oleh sebanyak 80 santri dan santriyah. Pendidikan kesehatan ini dilakukan oleh kelompok mahasiswa yang terdiri dari 8 orang anggota. Metode yang di gunakan adalah ceramah dan tanya jawab dengan pendekatan promosi kesehatan berupa pendidikan kesehatan tentang skabies. Pendidikan kesehatan ini berfokus pada pencegahan skabies yang sering terjadi di pesantren. Adapun tahapan yang di lakukan dapat dilihat Gambar 1.

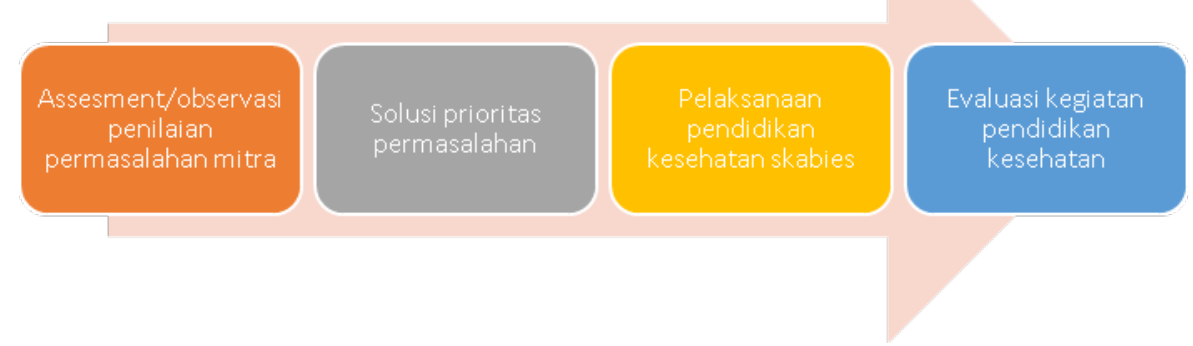

Gambar 2. Tahapan Pelaksanaan Kegiatan

$\begin{array}{llr}\quad \text { Tahapan } & \begin{array}{c}\text { persiapan } \\ \text { pelaksanaan } \\ \text { kegiatan }\end{array} & \begin{array}{r}\text { sebelum } \\ \text { dengan }\end{array} \\ \text { melakukan } & \text { assessment/observasi }\end{array}$ terlebih dahulu untuk menilai kriteria calon yang akan menjadi mitra kegiatan sekaligus objek tempat pelaksanaan kegiatan. Berdasarkan pertimbangan yang telah ditetapkan bersama, maka pada tahapan ini mitra kegiatan ditentukan, yaitu pondok pesantren AlArifin Ciamis. Pada tahapan ini dilakukan pula penilaian terhadap permasalahan-permasalahan yang ada di tempat mitra dan berdasarkan kesepakatan bersama maka solusi-solusi yang ditawarkan disepakati untuk dilaksanakan sesuai dengan prioritas utama.

Tahapan selanjutnya merupakan pelaksanaan kegiatan pendidikan kesehatan skabies, pada pelaksanaan pendidikan ini diberikan beberapa materi yang terkait dengan tema pendidikan kesehatan yang disampaikan yaitu terkait dengan pencegahan skabies yang sering terjadi di pesantren. Teknik yang di gunakan dalam penyampaian materi yaitu ceramah dan tanya jawab, adapun dengan medianya menggunakan leaflet dan power point presentation. Indikator keberhasilan dari pelaksanaan pendidikan kesehatan ini yaitu meningkatnya pengetahuan santri terhadap pencegahan skabies.

Evaluasi kegiatan dilakukan dengan memberikan pertanyaan kepada para santri untuk mengevaluasi sejauh mana pemahaman para santri mengenai pencegahan skabies, sehingga dapat dilihat tingkat keberhasilan program pendidikan kesehatan yang dilaksanakan.

\section{HASIL DAN PEMBAHASAN}


Henri Setiawan, dkk. Pendidikan Kesehatan Pencegahan Skabies Di Pondok Pesantren..

Pelaksanaan $r$
pendidikan kegiatan
diselenggarakan ini menggunakan
metode ceramah. Meteri yang
disampaikan pada pendidikan kesehatan
ini ditunjukan pada Gambar 3
diantaranya:

1) Pengertian skabies

2) Penyebab skabies

3) Cara penularan skabies

4) Cara pencegahan skabies

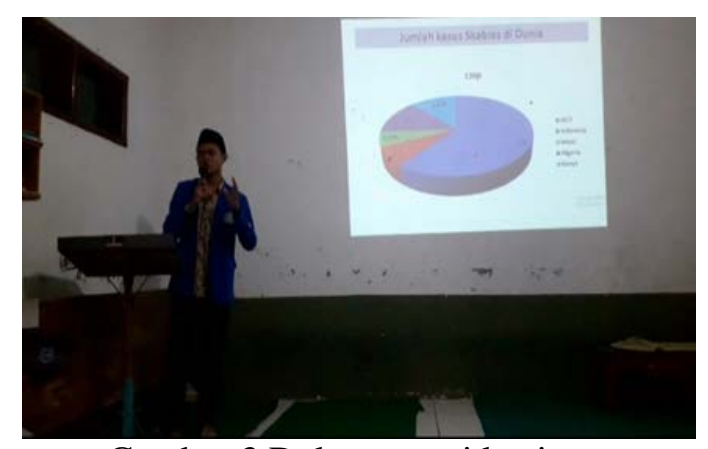

Gambar 3 Dokumentasi kegiatan
Pelaksanaan kegiatan dilakukan selama 2 jam sehingga materi yang disampiakan dapat dipahami oleh para santri kegiatan. Kegiatan pendidikan kesehatan ini dilaksanakan di Aula pondok pesantren Al-Arifin, peserta yang mengikuti kegiatan ini sebanyak 80 orang, maka disatukan didalam aula karena fasilitasnya yang lengkap. Upaya pengoptimalisasian dalam proses pemberian materi pendidikan kesehatan dilakukan dengan pembagian leflet.

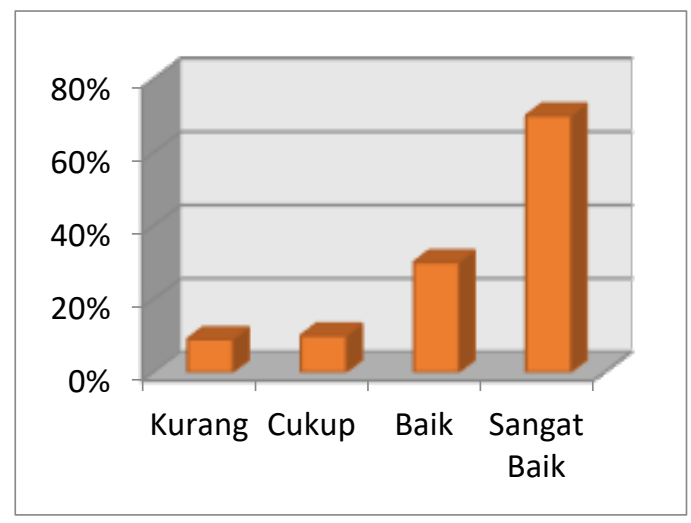

Gambar 4 Gambaran hasil penilaian kegiatan

$\begin{array}{clr}\text { Hasil } & \text { evaluasi } & \text { terhadap } \\ \text { pendidikan } & \text { kesehatan } & \text { yang }\end{array}$ dilaksanakan kepada para peserta kegiatan, didapatkan $70 \%$ menyatakan bahwa kegiatan ini secara keseluruhan sudah sangat baik, dan 30\% menyatakan Baik. Berdasarkan hasil evaluasi memberikan sebuah indikator bahwa kegiatan yang dilaksanakan secara garis besar dapat diterima oleh para peserta kegiatan dan dapat dipahami.

$$
\text { Sedangkan dalam hasil }
$$
pengamatan yang dilakukan selama pendidikan kesehatan $85 \%$ peserta memperhatikan tim penyuluh, indikatornya hampir semua peserta memahami cara pencegahan skabies. Peserta tampak menyimak dengan serius saat penyampaian materi. Peserta tampak antusias dan bersemangat dalam mengikuti pendidikan kesehatan karena banyak terlihat santri yang berperan aktif saat diajak berbicara oleh pemateri maupun saat pemateri memberikan pertanyaan.

\section{SIMPULAN}

Kegiatan pendidikan kesehatan skabies yang dilakukan di Pondok Pesantren Al-Arifin berjalan dengan lancar. Peserta mampu memahami materi yang disampaikan dengan baik. Peserta dapat menyebutkan apa itu skabies dan bagaimana cara pencegahannya. Peserta terlihat antusias, aktif dan bersemangat selama mengikuti kegiatan penkes.

Kegiatan penkes sangat memberikan manfaat dalam meningkatkan pengetahuan tentang kesehatan kepada masyarakat khususnya komunitas tertentu seperti di lingkungan pondok pesantren. Kegiatan ini perlu dilakukan secara lebih luas 
agar menambah pengetahuan kepada masyarakat terkait kesehatan.

\section{UCAPAN TERIMA KASIH}

Terima kasih pengabdi sampaikan kepada Pimpinan Pondok pesantren Al-Arifiin yang telah memberikan kesempatan dan peluang dalam kegiatan pengabdian ini.

\section{DAFTAR PUSTAKA}

Abedassar, S., Dehesh, T., Dehesh, S., \& Reza, H. (2020). A Survey to Oral Health Status and Oral Hygiene Behaviour of Orphan Children Located in Support Centres. Research Square, 1(1), $1-15$.

Anderson, K. L., \& Strowd, L. C. (2017). Epidemiology, diagnosis, and treatment of scabies in a dermatology office. Journal of the American Board of Family Medicine, 30(1), $\quad$ 78-84. https://doi.org/10.3122/jabfm.2 017.01.160190

Bear, U. R., Thayer, Z. M., Croy, C. D., Carol, E., Manson, S. M., Health, N., ... Building, $\mathrm{H}$. (2020). The impact of individual and parental American Indian boarding am Community Health school attendance on chronic physical health of Northern Plains Tribes. Family Comunity Health, 42(1), 1-7. https://doi.org/10.1097/FCH.00 00000000000205. The

Cheng, T., Mzahim, B., Alsugair, A., Al-Wabel, A., Almutairi, B., Maysa, E., \& Khan, C. (2020). Scabies: Application of the Novel Identify-Isolate-Inform Tool for Detection and
Management. Western Journal of Emergency Medicine, 21(2), 191-198.

https://doi.org/10.5811/westje m.2020.1.46120

Engelman, D., Yoshizumi, J., Hay, R. J., Osti, M., Micali, G., Norton, S., ... Fuller, L. C. (2020). The 2020 International Alliance for the Control of Scabies Consensus Criteria for the Diagnosis of Scabies. British Journal of Dermatology, 1-13. https://doi.org/10.1111/bjd.189 43

Erbenezer, E. (2019). ASSESSMENT OF PERSONAL HYGIENE AND FOOD SAFETY PRACTICES OF FOOD HANDLERS AMONG SELECTED SENIOR HIGH SCHOOLS IN THE KUMASI METROPOLIS, GHANA. Repository KWAME NKRUMAH UNIVERSITY.

Farihah, U., \& Azizah, R. (2017). Faktor Sanitasi Lingkungan yang Berhubungan dengan Skabies di Pondok Pesantren Qomaruddin Kabupaten Gresik. Departemen Kesehatan Lingkungan Fakultas Kesehatan Masyarakat Universitas Airlangga, 53(9), 1689-1699.

https://doi.org/10.1017/CBO97 81107415324.004

Fuhrmeister, E. R., Ercumen, A., Pickering, A. J., Jeanis, K. M., Crider, Y., Ahmed, M., ... Nelson, K. L. (2020). Effect of Sanitation Improvements on Pathogens and Microbial Source Tracking Markers in the Rural Bangladeshi Household Environment. Environmental Science and Technology, 54(7), 4316- 
Henri Setiawan, dkk. Pendidikan Kesehatan Pencegahan Skabies Di Pondok Pesantren..

4326.

https://doi.org/10.1021/acs.est. 9b04835

Haque, A., Nadeem, K., Bashir, S., Pirzado, B. A., Chachar, B., \& Khoso, J. khan. (2019). Prevalence of Scabies at dermatology Department PMCH Hospital Nawabshah. ASIAN PACIFIC JOURNAL OF NURSING AND HEALTH SCIENCES, 2(2), 1-6.

Heukelbach, J., \& Feldmeier, H. (2019). Scabies. Journal The Lancet, 367(1), 1767-1774.

Miftahurrizqiyah et al. (2018). Kejadian Skabies Berdasarkan Pemeriksaan Dermoskop, Mikroskop Dan Skoring Di Pondok Pesantren Al Ittifaqiah, $\mathrm{XX}(\mathrm{X})$.

Muller, L. I., \& Brinker, L. A. (2020). A Case of Scabies Presenting as Chronic Urticaria. MILITARY MEDICINE, 185(9r), 1854-1856. https://doi.org/10.1093/milmed /usaa040

Retha, \& Sawitri. (2020). Scabies in Children: A Retrospective Study. Periodical of Dermatology and Venereology, 32(1), 55-61.

Rosa et al. (2020). Hubungan antara Tingkat Pengetahuan Skabies dan Personal Hygiene dengan Kejadian Skabies di Puskesmas Selatan 1, Kecamatan Singkawang Selatan, 47(2), 97-102.

Sara, J., Haji, Y., \& Gebretsadik, A. (2018). Scabies Outbreak Investigation and Risk Factors in East Badewacho District, Southern Ethiopia: Unmatched Case Control Study. Hindawi Dermatology Research and Practice, 1(1), 1-10.

Srinivas, S., Herakal, K., Srinivasa Murthy, K., Suryanarayan, S., Firdaus, \& Monthi. (2019). Dermoscopic Study of Scabies in Children. Indian Journal of Paediatric Dermatology, 20(1), 46-51.

https://doi.org/10.4103/ijpd.IJP D

Uchejeso, O. M., \& Obiora, E. R. (2020). Hand Washing and Personal Hygiene among Nigerians in the face of COVID-19 ( Coronavirus ). American Journal of Biomedical Science \& Research, 1(1), 530-532. https://doi.org/10.34297/AJBS R.2020.08.001333.Received

Wijayanti, L., \& Ainiyah, N. (2019). the Effect of the Skin Personal Hygiene Modules As Health Education Media Against Knowledge in Prevention of Skabies. Nurse and Health: Jurnal Keperawatan, 8(1), 1. https://doi.org/10.36720/nhjk.v $8 \mathrm{i} 1.54$

Wochebo, W., Haji, Y., \& Asnake, S. (2019). Scabies outbreak investigation and risk factors in Kechabira district , Southern Ethiopia: unmatched case control study. BMC Research Notes, 12(305), 12-17. https://doi.org/10.1186/s13104019-4317-x 